\title{
PROSPECTIVE STUDY: CHARACTERISTICS AND THE PREVALENCE OF Helicobacter Pylori WITH GIT INFECTION IN BANI WALEED, LIBYA. Fatimah J. M. Abu Faris
}

Zoology Department, Faculty of Science, Bani waleed University, Libya. E-mail - Fatmaabofares86@gmail.com

Key Words: Helicobacter pylori; IgG-Anti-H. Pylori ELISA; H. pylori serology; Epidemiology; Bani Waleed; Prevalence.

\section{ABSTRACT:}

Helicobacter pylori infection is very common worldwide particularly in the developing countries. No detailed study on such infection is being recorded in Libya, so far in Bani Waleed. The aims of the study: Study aimed to detect H. pylori prevalence in asymptomatic Libyan subjects, especially in Bani Waleed to determine the rate of infection among different age groups and to correlate the prevalence of $\mathrm{H}$. pylori with age and sex status. Used in this study 1712 asymptomatic case from 1 up to 84 years of age (average 36 ) with no previous history of epigastric pain were selected randomly from the Libyan population, especially in Bani Waleed. Serum samples were obtained and a questionnaire was filled for each case. The ELISA test was used to detect IgG anti-H. Pylori antibodies.

No difference in sex was recorded. Otherwise, Negative H. Pylori IgG in female was significantly elevated $(34.7 \%)$ in compared to $(27.8 \%)$ in male Patients. Furthermore, number of persons living in the same household as well as number of siblings in family also significantly affected the $\mathrm{H}$. Pylori seropositivity in the present recruited populations. It could be concluded that, Helicobacter pylori infection had significantly correlated with peptic ulcer diseases than those of non-ulcer dyspepsia. The prevalence of $\mathrm{H}$. pylori in the developing countries, especially in Bani Waleed is still high in the healthy asymptomatic population while, no difference upon the gender.

\section{INTRODUCTION:}

Helicobacter pylori (H.pylori) infection considered as one of the most common bacterial infections in humans. It is estimated that more than half of the world populations are currently infected with this organism (1). The prevalence of such infection ranges from $25 \%$ in developed countries to $>90 \%$ in developing countries (2). Reports on the prevalence of H.pylori infection in dyspeptic patients from other developing countries in the region support these figures. Helicobacter pylori is associated with a number of serious digestive tract diseases including chronic gastritis, peptic ulcers, mucosa-associated changes to 
lymphoma and gastric cancers in adults. Striking differences exist in the prevalence of $\mathrm{H}$. Pylori infection among people of various professions, ethnic and social background.

High prevalence rates reported in Greek, Italian, Lebanese, Chinese, Vietnamese and Algerians. In contrast, Australian aboriginals have very low H. Pylori prevalence (3). However, in healthy Libyan population, the prevalence of $\mathrm{H}$. Pylori infection is not well known (4). In one of our recent data, however, we reported the rate of infection in a group of dyspeptic patients to be around $82 \%$ (5). In addition, the validation of IgG serology in diagnosis of $\mathrm{H}$. Pylori infection was undertaken too. Serologic tests for H. Pylori-IgG are essential epidemiologic tool for examining $\mathrm{H}$. Pylori associated manifestations in the community. The purpose of this work was to provide important answers on the seroprevalence of $\mathrm{H}$. Pylori IgG in apparently healthy individuals according to gender status, which may be has any effect on the prevalence. We conducted a relatively large based, controlled study in Bani Waleed area; located in the Tripoli District of Libya.

\section{MATERIALS AND METHODS:}

Serum samples from 1,712 asymptomatic individuals whose attended Ibn Sina, Alnokhba and Aldahra Laboratories, Bani Waleed, Libya. H. Pylori-IgG antibody was evaluated using the commercially available Cobas Core Enzyme Immunoassay method (Roche SA, Basel, Switzerland). Study conducted of 840 males and 872 females at various age categories (Mean 36.3 year, age range 1-84 years). They were considered asymptomatic after they denied any clear, continuous gastrointestinal complain during the 2-3 months before. Cuba's Core anti-H. Pylori ELISA kit has been previously validated in Bani Waleed dyspeptic patients and was found to have adequate accuracy (Sensitivity $99 \%$ and specificity $88 \%$ ) (5). Results were expressed as numbers and percentages. Comparison of percentages were assessed using chi-square test on SPSS software version 22. Pearson correlation wase made between antibody responses and gender status. Statistical significance was determined by $\mathrm{P} \leq 0.05$.

\section{RESULTS:}

The represented data of $\mathrm{H}$. Pylori seroprevalence present in 1.712 individuals suffering from GIT symptoms. The effects of gender on HP seropositivities is. H. Pylori IgG evaluated in 840 males compared to 872 of females. There was no significant differences according to gender. However, the percentage of Positive H. Pylori IgG was $47.5 \%$ in males in compared with $43.8 \%$ acording to the total number in the same gender. 
On the other hand, there are no significant differences between male $(12.8 \%)$ and female (13.8\%) in Strong H. Pylori IgG. Otherwise, Negative H. Pylori IgG in Female was significantly elevated $(34.7 \%)$ in compared to $(27.8 \%)$ in Male Patients. Furthermore, number of persons living in the same household as well as number of siblings in family also significantly affected the $\mathrm{H}$. Pylori seropositivity in the present recruited populations. In respect to smoking, data proved no significant association of this factor and H. Pylori sero-prevalence.

Table : Analysis of H. Pylori seropositivies according the different gender.

\begin{tabular}{|c|c|c|c|c|c|}
\hline Gender & Total & Positive (+ve) & Strong (+ve) & Weak (+ve) & Negative (+ve) \\
\hline & 840 & 399 & 108 & 99 & 234 \\
\hline Male & $\%$ Percentage & $47.5 \% *$ & $12.8 \%$ & $11.8 \% *$ & $27.8 \%$ \\
\hline & 872 & 382 & 120 & 67 & 303 \\
\hline Female & $\%$ Percentage & $43.8 \%$ & $13.8 \%$ & $7.7 \%$ & $34.7 \% *$ \\
\hline
\end{tabular}

Statistical significance * was determined by $P \leq 0.05$.

\section{DISCUSSION:}

The epidemiology of $\mathrm{H}$. pylori infection in Libyan population remains important for public health investigation because of high prevalence of this infection and its association with peptic ulcers and chronic dyspepsia (5). Compared to similar studies, this work is, to our knowledge, the first and the largest on $\mathrm{H}$. Pylori seroprevalence in a selected group of normal population at various ages in Bani Waleed. There is sparse information on H. Pylori seropositivity rates in Libyan populations on locally validated serological tests (4). The study are in accordance with Mohammad et al. (6) showed that, in the developing countries, no significant differences, H. Pylori infection attributable to gender (6). In contrast to, the negative H. pylori cases in Female higher than Male.

\section{CONCLUSION:}

Helicobacter pylori infection is significantly correlated with peptic ulcer diseases than with non-ulcer dyspepsia. The prevalence of H. pylori in the developing countries, especially in Bani Waleed is still high in the healthy asymptomatic population while, no difference upon the gender. Strategies to improve sanitary facilities, educational status, and 
socioeconomic status should be implemented to minimize H. pylori infection.

\section{ACKNOWLEDGEMENT:}

The study appreciate the participate of Dr. Ahmed Saber Hussein, Lecturer of Animal Physiology, Faculty of Science, Al_Azhar University, Cairo, Egypt and all of the staff Ibn Sina, Alnokhba and Aldahra Laboratories in Bani Waleed.

\section{REFERENCES:}

1. Kimmel, B. ; A.Bosserhoff ; R. Frank ; R. Gross ; W. Goebel and D. Beier (2000). Identification of immunodominant antigens from Helicobacter pylori and evaluation of their re activities with sera from patients with different gastroduodenal pathologies. Infection and immunity, 68(2): 915-920.

2. Bardhan, P.K. (1997). Epidemiological features of Helicobacter pylori infection in developing countries. Clinical infectious diseases, 25(5): 973-978.

3. Brown, L. M. (2000). Helicobacter pylori: epidemiology and routes of transmission. Epidemiologic reviews, 22(2): 283-297.

4. Salih, B.A. ; A.M. Naji ; M. Bushala and R. Tobji (1996). Serological diagnosis of Helicobacter pylori infection in individuals with gastritis and in normal controls. In Jamahiriya $3 r d$ Conference on medical sciences (Vol. 152).

5. Bakka, A. ; M.A. Mohammad ; M. Altayar ; A.B. Toboloi ; A. Gariena and M. Boushala (2009). Helicobacter pylori infection among Libyan chronic dyspeptic patients in Benghazi. Libyan J Inf Dis, 3: 30-36.

6. Mohammad, M.A. ; M. Altayar ; A.B. Toboli and A. Bakke (2011). Characteristics of helicobacter pylori infection in Libyan healthy peoples in two teaching hospitals in ben ghazi. Medical Journal of Islamic World Academy of Sciences, 19 (1): 27-32.

$$
\begin{aligned}
& \text { دراسة محتملة : خصائص انتشار عدوي جرثومة المعدة من حيث الجنس في } \\
& \text { بني وليد ، ليبيا. }
\end{aligned}
$$

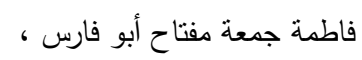

$$
\begin{aligned}
& \text { قسم علم الحيوان ، كلية العلوم ، جامعة بني وليد ، ليبيا. }
\end{aligned}
$$

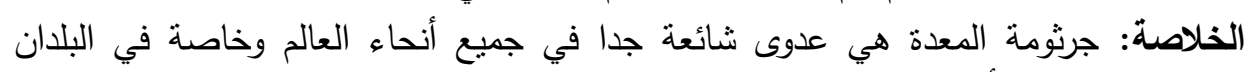

$$
\begin{aligned}
& \text { النامية. ولم تسجل أي دراسة تفصيلية عن منل هذه الإصابة في ليبيا حتى الآن في بني وليد. }
\end{aligned}
$$


هدفت الدراسة إلى عمل مسح لعدد كبير من الأثخاص داخل اكبر المعامل الموجودة في بني

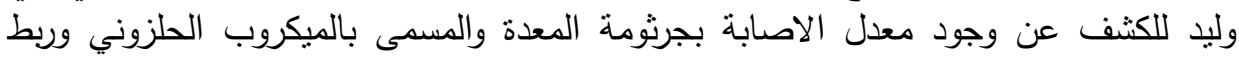
معدل الاصابة بالحالة العمرية ونوع الجنس.

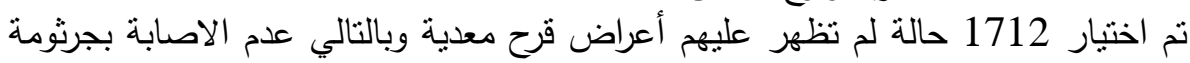

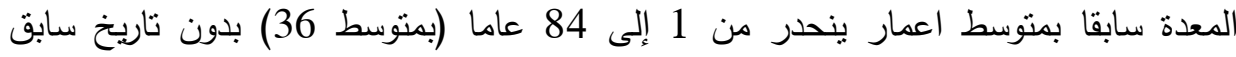

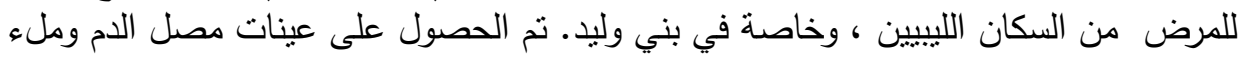

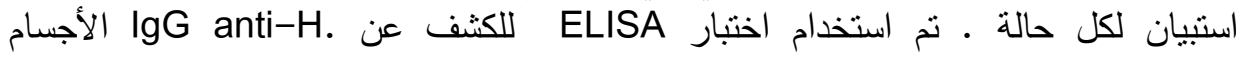

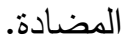

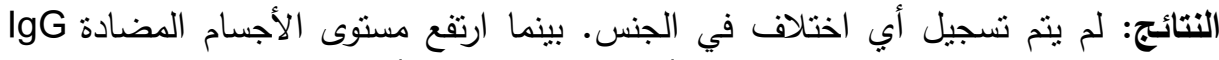

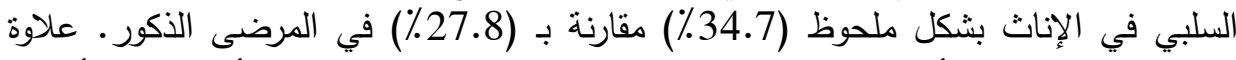

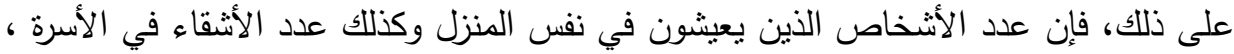

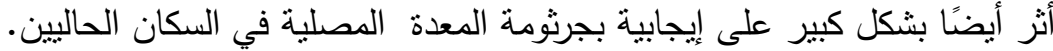

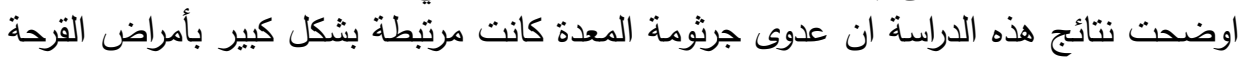

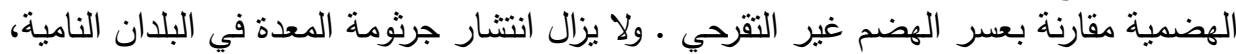

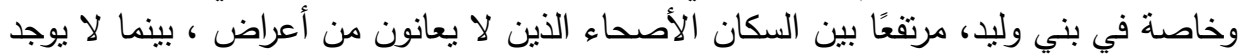

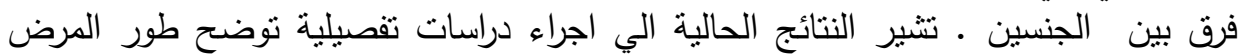

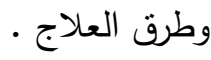

